\title{
REVITALISASI PRODI PENDIDIKAN ADMINISTRASI PERKANTORAN FIS UNY (Aspek Kesejarahan dan Kurikulum)
}

\author{
Oleh: Sugi Rahayu \\ sugirahayu@uny.ac.id

\section{A. Sejarah PSPAP FIS UNY}

Berbicara tentang aspek kesejarahan Program Studi Pendidikan Administrasi Perkantoran Fakultas IImu Sosial Universitas Negeri Yogyakarta (PSPAP FIS UNY) tidak dapat dilepaskan dari sejarah berdirinya FIS UNY, yang secara ringkas adalah sebagai berikut:

1. IKIP Yogyakarta lahir berdasarkan Keputusan Menteri Perguruan Tinggi dan IImu Pengetahuan (PTIP) Nomor 55 tahun 1963, tanggal 22 Mei 1963. Salah satu fakultasnya adalah Fakultas Keguruan Pengetahuan Sosial (FKPS) yang diresmikan oleh Menteri PTIP tanggal 21 Mei 1964. Keputusan ini dikuatkan dengan Keputusan Presiden RI Nomor 268 Tahun 1965, tanggal 14 September 1965. Dalam rangka memantapkan fungsi keguruan di bidang IImu Sosial, rektor IKIP Yogyakarta mengeluarkan surat Keputusan Nomor 05 tahun 1965 yang isinya antara lain pergantian nama FKPS menjadi Fakultas Keguruan IImu Sosial (FKIS).

2. Berdasarkan Keputusan Presiden RI No. 54 tahun 1982 tertanggal 7 September 1982 FKIS berubah menjadi Fakultas Pendidikan IImu Pengetahuan Sosial (FPIPS).

3. Selaras dengan perkembangan IPTEKS dan tuntutan dunia kerja, IKIP Yogyakarta dikembangkan menjadi Universitas Negeri Yogyakarta (UNY) berdasarkan keputusan Presiden RI Nomor 93 tahun 1999, tanggal 4 Agustus 1999. Hal ini diikuti dengan perubahan nama fakultas di lingkungan UNY, FPIPS berubah menjadi FIS, yang disahkan berdasarkan Keputusan Menteri Pendidikan dan Kebudayan Nomor 274/0/1999.

4. Berdasarkan Peraturan Menteri Pendidikan Nasional RI Nomor 12 Tahun 2006, FIS berubah menjadi Fakultas Ilmu Sosial dan Ekonomi (FISE) dan pada tanggal 22 Juni FISE berkembang menjadi dua fakultas, Yaitu FIS dan FE.

Sejak awal berdirinya IKIP/UNY, nama Jurusan IImu Administrasi (FKIS) sudah ada, namun dalam perjalanannya mengalami berbagai perubahan. Perubahan tersebut adalah:

1. Keputusan Menteri Pendidikan dan Kebudayaan RI No. 0554/O/1983 tentang Jenis dan Jumlah Jurusan pada Fakultas di Lingkungan IKIP Yogyakarta dan diperkuat dengan Keputusan Dirjen Dikti No. 31/Dikti/Kep/1984 tentang Jenis dan Jumlah Program Studi di Setiap Jurusan pada Fakultas di Lingkungan IKIP Yogyakarta, pada FPIPS IKIP Yogyakarta terdapat Jurusan Pendidikan Dunia Usaha (PDU) dengan Program Studi: (1) Pendidikan Administrasi Perkantoran, (2) Pendidikan Akuntansi, (3) Pendidikan Koperasi. Keputusan ini menggabungkan tiga jurusan yang semula berdiri sendiri, yaitu Jurusan Ilmu Administrasi, Ekonomi Perusahaan, dan Ekonomi Koperasi. Di sini Jurusan Ilmu Administrasi turun menjadi Program Studi. 
2. Keputusan Dirjen Dikti No. 245/Dikti/Kep/96 tertanggal 11 Juli 1996 tentang Program Studi pada Program Sarjana di lingkungan IKIP Yogyakarta. Jurusan PDU sudah tidak muncul, akan tetapi muncul Program Studi Pendidikan Ekonomi. Dalam Program Studi Pendidikan Ekonomi inilah tiga prodi yaitu Pendidikan Administrasi Perkantoran, Pendidikan Akuntansi, dan Pendidikan Koperasi berstatus sebagai Bidang Keahlian Khusus (BKK).

3. Berdasarkan Surat Dirjen Dikti No. 3204/D/T/2002 BKK-BKK: Pendidikan Administrasi Perkantoran, Pendidikan Akuntansi, dan Pendidikan Ekonomi Koperasi berkedudukan sebagai Program Studi.

4. Program Studi Pendidikan Administrasi Perkantoran sekarang berada di Jurusan pendidikan Administrasi.

\section{B. Kurikulum PSPAP FIS UNY}

Kurikulum merupakan perangkat pelajaran yang diberikan oleh suatu lembaga penyelenggara pendidikan yang berisi rancangan pelajaran yang akan diberikan kepada peserta pelajaran dalam satu periode jenjang pendidikan. Penyusunan perangkat mata pelajaran ini disesuaikan keadaan dan kemampuan setiap jenjang pendidikan dalam penyelenggaran pendidikan tersebut (Wikipedia Bahasa Indonesia (diunduh tanggal 27 Juli 2011).

Kurikulum pendidikan tinggi adalah seperangkat rencana dan pengaturan mengenai isi maupun bahan kajian dan pelajaran serta cara penyampaian dan penilaian yang digunakan sebagai pedoman penyelenggaraan kegiatan belajar-mengajar di perguruan tinggi (Pedoman Kurikulum KBK Pendidikan Tinggi, Kemendiknas, 2008: 5).

Kurikulum lembaga pendidikan harus senantiasa dikembangkan mengikuti tuntutan perkembangan masyarakat.Enco Mulyasa (2004: 67) mengemukakan bahwa kurikulum dapat dikembangkan atas dasar dua pendekatan yaitu sistem pengelolaan dan fokus sasaran. Pendekatan sistem pengelolaan berorientasi pada kewenangan pengembangan dan penentuan muatan kurikulum. Pendekatan ini terkait dengan sistem pemerintahan yang digunakan suatu negara, khususnya dengan sistem sentralisasi dan desentralisasi (otonomi) kekuasaan. Sejalan dengan sistem tersebut maka pengembangan kurikulum dapat dibedakan menjadi dua pola yaitu sentralistik dan desentralistik. Pada pola sentralisasi, kurikulum disusun oleh pengambil kebijakan pada tingkat pusat sedangkan daerah tinggal melaksanakan. Sebaliknya pada pola desentralisasi, daerah diberikan kewenangan untuk menentukan kurikulum sesuai dengan potensi dan karakteristik masing-masing daerah. Sementara itu, pada pendekatan sasaran, pengembangan kurikulum dikelompokkan berdasarkan bidang-bidang sasaran sebagai berikut: penguasaan ilmu pengetahuan, pengembangan potensi yang ada pada peserta didik, pembentukan pribadi, pemecahan masalah kemasyarakatan. 
Pada saat ini PSPAP menerapkan Kurikulum FISE UNY tahun 2009, menggantikan kurikulum sebelumnya yaitu Kurikulum 2002. Dalam penyusunannya Kurikulum 2009 sudah melibatkan berbagai pihak yang berkepentingan dengan tuntutan kompetensi lulusan. Dengan prosedur seperti itu diharapkan lulusan PSPAP memiliki kompetensi sesuai dengan visi, misi, dan tujuannya.

\section{Visi, Misi, Tujuan, Kompetensi Lulusan, dan Struktur Kurikulum PSPAP adalah:}

1. Visi

Mewujudkan Program Studi unggulan dalam menghasilkan tenaga kependidikan di bidang Administrasi Perkantoran, yang mampu berpikir kritis, analitis, responsif terhadap fenomena keadministrasian, berkepribadian Indonesia yang religius, dan komitmen terhadadp prinsip efisiensi.

\section{Misi}

a. Menyelenggarakan pendidikan, penelitian, dan pengabdian kepada masyarakat dalam rangka membentuk tenaga kependidikan yang handal di bidang Administrasi Perkantoran.

b. Mengembangkan sistem pendidikan yang mampu membekali lulusan yang memiliki fleksibilitas, kepribadian nasional religius, kearifan dan responsif terhadap perkembangan dan permasalahan ipteks.

c. Membangun budaya akademik dan jiwa wirausaha yang mendorong ketajaman nurani lulusan.

d. Membangun sistem kelembagaan untuk mengembangkan fungsi Program Studi Pendidikan Administrasi Perkantoran.

\section{Tujuan}

a. Menghasilkan tenaga kependidikan bidang administrasi perkantoran yang profesional.

b. Menghasilkan tenaga kependidikan bidang Administrasi Perkantoran yang mampu berfikir, bersikap, dan bertindak sebagai pendidik yang kompeten.

c. Menghasilkan tenaga kependidikan yang mampu menemukan, memahami, menjelaskan, merumuskan, dan mengembangkan cara menyelesaikan masalah di bidang Administrasi Perkantoran.

d. Menghasilkan tenaga kependidikan yang mampu mengikuti dan mengembangkan pengetahuan dan teknologi Administrasi Perkantoran. 


\section{Kompetensi Lulusan}

Lulusan Program Studi Pendidikan Administrasi Perkantoran diharapkan:

a. Mampu melaksanakan tugas profesioanal tenaga kependidikan dalam pembelajaran Administrasi Perkantoran.

b. Mampu melaksanakan tugas tambahan bidang Administrasi Perkantoran di luar profesi tenaga kependidikan

c. Mampu melaksanakan tugas kajian bidang Administrasi Perkantoran untuk kepentingan pembelajaran, penelitian, maupun pengabdian kepada masyarakat.

d. Mampu mengikuti dan mengembangkan pengetahuan dan teknologi bidang Administrasi Perkantoran.

\section{Struktur Kurikulum}

Sesuai dengan SK Mendiknas No. 232/U/2000 dan SK No. 045/U/2002, sebagai kurikulum berbasis kompetensi, maka struktur kurikulum untuk PSPAP, sebagai berikut:

1) Mata kuliah Pengembangan Kepribadian (MPK) 13 sks

2) Mata kuliah Keilmuan dan Keterampilan (MKK) 26 sks

3) Mata kuliah Keahlian Berkarya (MKB) .......... 81 sks

4) Mata kuliah Perilaku Berkarya (MPB)............ 21 sks

5) Mata kuliah Berkehidupan Bermasyarakat (MBB) .. 6 sks

Sebaran matakuliah selengkapnya dapat diperiksa pada Kurikulum PSPAP FISE UNY 2009.

Berdasarkan hasil tracer study yang pernah dilakukan, ternyata tidak semua lulusan PSPAP menjadi guru. Tidak kurang dari $30 \%$ lulusan yang menjadi subyek penelitian berprofesi di bidang administrasi perkantoran atau di luar bidang keguruan. Di antara mereka ada yang menjadi kepala biro, kepala bagian, pegawai bank, kepala pusat penelitian, maupun wirausahawan yang berhasil. Ini menunjukkan bahwa PSPAP adalah program studi yang luwes.

Selama ini dirasakan adanya pandangan masyarakat yang kurang tepat terhadap Adiministrasi Perkantoran. Orang lebih sering mengenal pekerjaan perkantoran sebagai pekerjaan tatausaha. Pandangan ini tidak terlalu salah tetapi orang sering lupa akan pentingnya peran pekerjaan tatausaha. Orang menganggap tatausaha adalah pekerjaan yang dapat dilakukan oleh siapa saja tanpa harus memiliki keterampilan khusus yang diperoleh melalui proses pendidikan yang lama seperti jenjang Strata 1 (S1). Pandangan seperti ini sangat merugikan bidang administrasi perkantoran, baik dalam posisinya sebagai kegiatan praksis pendukung proses kerjasama (suatu organisasi) maupun dalam pengembangan ilmu.

Pandangan keliru tersebut perlu diluruskan agar administrasi perkantoran dapat dikembangkan secara proporsional. Hal ini sesuai dengan yang disampaikan oleh Muhyadi 
(2011:4) bahwa sebagai bidang kerja yang mengelola informasi, administrasi perkantoran menempati posisi strategis dalam setiap organisasi. Kenyataan yang ada menunjukkan bahwa posisi informasi sangat vital dalam mendukung keberhasilan organisasi. Tampaknya kini orang mulai menyadari betapa pentingnya peran informasi bagi pengambilan keputusan organisasi. Kenyataan ini kemudian mengubah cara pandang orang terhadap informasi termasuk segala sesuatu yang terkait dengan pengelolaan informasi. Wajah kantor -tempat dimana informasi dikelola- tidak lagi terkesan kumuh dengan tumpukan berkas-berkas arsip yang berdebu dan karyawan yang lusuh. Selain lebih tertata rapi, kini posisi kantor lebih 'bermatabat', dengan kondisi fisik yang jauh lebih baik dan kinerja SDM yang jauh lebih efisien. Yang lebih penting dari itu semua, posisi kantor sebagai pusat informasi menjadi semakin strategis dalam menjaga kelangsungan hidup dan bahkan mengembangkan organisasi, apapun bentuk organisasi yang bersangkutan. Oleh karena itu pekerjaan kantor harus dikelola secara efisien.

Seiring dengan perubahan yang luar biasa di bidang teknologi dan komunikasi, perubahan yang signifikan juga terjadi pada bidang administrasi, utamanya pada pola pengelolaan informasi, baik jenis, penggunaan, maupun perlakuan terhadap bahan informasi. Perubahan ini harus diimbangi dengan menyiapkan strategi yang tepat untuk menghadapinya. Untuk itu peningkatan kualitas sumberdaya manusia (SDM) bidang Administrasi Perkantoran harus dilakukan secara berkelanjutan. Program Studi Pendidikan Administrasi Perkantoran sebagai bagian dari sistem pendidikan tidak luput dari kondisi tersebut jika ingin survive. PSPAP dituntut untuk tanggap (responsif) terhadap berbagai perubahan yang terjadi dan mampu merespon dengan benar. Sebagai subsistem pendidikan, PSPAP merupakan lembaga pelayan masyarakat yang keberadaannya dalam rangka memenuhi kebutuhan pelanggan. Oleh karena itu lulusan yang dihasilkan harus senantiasa menyesuaikan dengan kebutuhan pelanggan/pasar. Tuntutan pasar terkait dengan jumlah dan kompetensi lulusan mengalami perubahan dari waktu ke waktu. Menghadapi kondisi seperti ini mau tidak mau PSPAP harus mengakomodasinya jika ingin lulusannya diterima pasar.

Telah disebutkan bahwa tujuan utama PSPAP adalah menghasilkan tenaga kependidikan bidang administrasi perkantoran yang profesional. Lulusan PSPAP diharapkan mampu menjadi guru yang profesional di bidang administrasi perkantoran. Lembaga pendidikan yang cocok untuk mengabdikan ilmunya adalah SMK. Berdasarkan Keputusan Dirjen Mandikdasmen No. 251/C/Kep/MN/2008 dalam Spektrum Kurikulum SMK terdapat enam bidang keahlian, salah satunya adalah Bidang Keahlian Bisnis dan Manajemen. 
Bidang Keahlian Bisnis dan Manajemen mencakup:

\begin{tabular}{|l|l|l|}
\hline \multicolumn{1}{|c|}{ Bidang Keahlian } & Program Studi Keahlian & \multicolumn{1}{|c|}{ Kompetensi Keahlian } \\
\hline Bisnis dan Manajemen & Administrasi & Administrasi Perkantoran \\
\cline { 2 - 3 } & Keuangan & Akuntansi \\
\cline { 2 - 3 } & & Perbankan \\
\cline { 2 - 3 } & Tata niaga & Pemasaran \\
\hline
\end{tabular}

Dalam Spektrum tersebut, Kompetensi Keahlian Administrasi Perkantoran lulusannya diharapkan menunjukkan kemampuan: (1) Bekerja sama dengan kolega dan pelanggan, (2) Mengikuti prosedur keamanan, keselamatan, dan kesehatan kerja, (3) Berkomunikasi melalui telepon, (4) Menggunakan peralatan kantor, (5) Merencanakan dan melakukan pertemuan., (6) Melakukan prosedur administrasi, (7) Mengikuti aturan kerja sesuai dengan lingkungan kerja, (8) Menjaga dan melindungi budaya kerja, (9) Mengatur penggandaan dan pengumpulan dokumen (10) Menangani surat masuk dan keluar, (11) Membuat dan menjaga sistem kearsipan untuk menjamin integritas, (12) Mencatat dikte untuk mempersiapkan naskah, (13) Menghasilkan dokumen sederhana, (14) Menciptakan dan mengembangkan naskah untuk dokumen, (15) Mengatur perjalanan bisnis, (16) Memberikan pelayanan kepada pelanggan, (17) Mengaplikasikan keterampilan dasar komunikasi, (18) Memproses transaksi keuangan.

Hasil penelitian yang dilakukan Muhyadi (2009) menunjukkan bahwa secara substantif Kurikulum PSPAP 2009 relevan dengan Spektrum Kompetensi Keahlian Administrasi Perkantoran tersebut.

Selanjutnya Dalam Buku 4 Rambu-Rambu Pelaksanaan PLPG (p: 82) disebutkan bahwa:

\begin{tabular}{|c|c|c|c|c|c|}
\hline $\begin{array}{l}\text { Bidang } \\
\text { Keahlian }\end{array}$ & $\begin{array}{l}\text { Program } \\
\text { Studi } \\
\text { Keahlian }\end{array}$ & $\begin{array}{l}\text { Kompetensi } \\
\text { Keahlian }\end{array}$ & Kode & Prodi Penilai & $\begin{array}{l}\text { Instruktur } \\
\text { dan Asesor }\end{array}$ \\
\hline \multirow[t]{5}{*}{$\begin{array}{l}\text { Bisnis dan } \\
\text { Manajemen }\end{array}$} & \multirow[t]{2}{*}{ Administrasi } & \multirow[t]{2}{*}{$\begin{array}{l}\text { Administrasi } \\
\text { Perkantoran }\end{array}$} & 539 & $\begin{array}{l}\text { Pendidikan } \\
\text { Administrasi } \\
\text { Perkantoran }\end{array}$ & \multirow[t]{2}{*}{$\begin{array}{l}\text { Administrasi } \\
\text { Perkantoran }\end{array}$} \\
\hline & & & & $\begin{array}{l}\text { Pendidikan } \\
\text { Manajemen } \\
\text { Perkantoran }\end{array}$ & \\
\hline & \multirow[t]{2}{*}{ Keuangan } & Akuntansi & 540 & $\begin{array}{l}\text { Pendidikan } \\
\text { Akuntansi }\end{array}$ & Akuntansi \\
\hline & & Perbankan & 543 & $\begin{array}{l}\text { Pendidikan } \\
\text { Akuntansi } \\
\text { Pendidikan } \\
\text { Ekonomi } \\
\end{array}$ & $\begin{array}{l}\text { Akuntansi } \\
\text { Ekonomi }\end{array}$ \\
\hline & Tata niaga & Pemasaran & 615 & $\begin{array}{l}\text { Pendidikan Tata } \\
\text { Niaga }\end{array}$ & Tata Niaga \\
\hline
\end{tabular}




\section{Penutup}

Dengan melakukan analisis terhadap sejarah, kurikulum, dan pasar bagi lulusan Program Studi Pendidikan Administrasi Perkantoran FIS UNY dapat ditarik benang merah bahwa Program Studi Pendidikan Administrasi Perkantoran FIS UNY merupakan program studi yang serumpun dengan Program Studi Pendidikan Akuntansi dan Pendidikan Ekonomi yang saat ini bernaung di bawah Fakultas Ekonomi (FE) UNY.

Pengembangan FISE menjadi FIS dan FE membawa implikasi kepada keberadaan PSPAP. Dari sisi keilmuan PSPAP sebagaimana Program Studi Pendidikan yang lain yang berada di FIS, di sisi lain untuk kepentingan pasar dan pengembangan kelembagaan apabila masih bernaung di bawah FIS tidak terakomodasi oleh kebijakan pemerintah. Hal ini diperkuat dengan hasil studi banding yang telah dilakukan di berbagai perguruan tinggi eks IKIP yang mendapat wider mandate, bahwa Program Studi Pendidikan Administrasi Perkantoran atau Pendidikan Manajemen Perkantoran sudah masuk ke Fakultas Ekonomi. Menghadapi kondisi tersebut PSPAP FIS UNY harus meresponnya secara benar dan arif, sehingga berdampak positif bagi program studi dan warganya

\section{Daftar Pustaka}

Buyung Ahmad Syafei, Kompeten dan Kompetensi (F:/Kompeten dan Kompetensi <thought's.htm> (diunduh: 29 September 2010)

Enco Mulyasa. 2004. Kurikulum Tingkat SatuanPendidikan: Konsep, Karakteristik, danImplementasi. Bandung: ERemajaRosdaKarya.

Muhyadi, 2009. Relevansi Kurikulum Program Studi Kependidikan di FISE LNY dengan Kebutuhan Sekolah. Yogyakarta: FISE UNY. Hasil Penelitian.

Standar Kompetensi Kerja Nasional Indonesia (SKKNI) Bidang Administrasi Perkantoran. 2007. Kepmenakertrans RI, Nomor: KEP.195/MEN/IV/2007.

(file:///F:/Office Administration.htm). (diunduh: 28 September 2010).

Wikipedia, The Free Encyclopedia, Office Administration. F:/Office_Administration.htm (diunduh: 26 September 2010)

Keputusan Mendikbud No. 0554/O/1983 tentang Jenis dan Jumlah Jurusan pada Fakultas di Lingkungan IKIP Yogyakarta 
Keputusan Dirjen Dikti No. 31/Dikti/Kep/1984 tentang Jenis dan Jumlah Program Studi di Setiap Jurusan pada Fakultas di Lingkungan IKIP Yogyakarta.

Keputusan Dirjen Dikti No. 245/Dikti/Kep/96 tertanggal 11 Juli 1996 tentang Program Studi pada Program Sarjana di lingkungan IKIP Yogyakarta.

Surat Dirjen Dikti No. 3204/D/T/2002 tentang ljin Penyelenggaraan Program-Program Studi Jenjang Program sarjana (S1) pada Universitas Negeri Yogyakarta.

Sejarah FIS UNY diundah dari uny.ac.id pada tanggal 27 April 2012. 